Diana Andreescu

Associated Professor, PhD in Arts

Faculty of Arts and Design

West University of Timisoara

Timisoara, Romania

E-mail: diana.andreescu@e-uvt.ro

\title{
Cultural Heritage through Design Thinking
}

\section{Abstract:}

The general purpose of the Design Thinking approach (concept taken over in Romanian without its translation and which involves conception-oriented thinking) is to support the conception and design of products, services, processes, strategies, spaces, architecture and experiences ideal for use optimal. Applying the approach leads to the development of practical and innovative solutions to the problems identified in the product and / or technology design departments of companies. As described in the article Design Thinking is a process springing from the user-centered conceptiondesign paradigm. The objective of the article is to highlight the need to combine urban study within Design Thinking, in the case of all areas of conception-design of solutions.

Keywords: design thinking, innovation, creativity, experience, empathy, thinking, consumer, health.

\author{
Diana Andreescu \\ Conf.univ.dr \\ Departamentul Design si Arte Aplicate \\ Facultatea de Arte si Design \\ Universitatea de Vest din Timisoara, Romania \\ E-mail: diana.andreescu@e-uvt.ro
}

\section{Patrimoniul cultural prin metoda Design Thinking}

\section{Abstract:}

Scopul general al abordării Design Thinking (concept preluat în limba română fără traducerea sa și care implică gândirea orientată spre concepție) este de a sprijini concepția și proiectarea produselor, serviciilor, proceselor, strategiilor, spațiilor, arhitecturii și experiențelor ideale pentru utilizare optimă. Aplicarea abordării duce la dezvoltarea de soluții practice și inovatoare la problemele identificate în departamentele de proiectare a produselor și / sau tehnologiilor companiilor. Așa cum este descris în articolul Design Thinking este un proces izvorât din paradigma de concepțieproiectare centrată pe utilizator. Obiectivul articolului este de a evidenția necesitatea de a combina studiul urban în cadrul Design Thinking, în cazul tuturor domeniilor de concepție-proiectare a soluțiilor.

Cuvinte cheie: gândire de design, inovație, creativitate, experiență, empatie, gândire, consumator, sănătate. 


\section{Introduction}

Timisoara is a strong micro-regional center, with a cultural history as old as the city. It is the city where creativity supports the experiment and where the dynamics of cultural life are connected to the international phenomenon. It is a charming city through its diversity, fascinating through its cultural and intercultural production and offer, but also through its existing heritage. In the context of a Cultural Strategy for the city of Timisoara, based on interdisciplinarity and creativity, multiculturalism and vivacity, the initiative of the Faculty of Arts and Design within the West University of Timisoara, through the project Together for the city aims to join cultural operators in Timisoara. The city to become European Capital of Culture in 2023.

The cultural heritage of Timisoara stands out as an extremely generous cultural and identity resource, which deserves to be cultivated and valued. Timisoara has an impressive number of buildings located in protected historical areas or protection: over 14,000, but when it comes to buildings that are in a state of severe degradation, the percentage is bleak: over 90\%. 2018 - European Year of Cultural Heritage and the moment TM2023 - European Capital of Culture is the occasion for which Timisoara has started an extensive process of information and awareness of public opinion and all decision makers involved in this process, on the complex issue of restoration and immediate intervention of historic buildings.

In Romania, architectural restoration is a niche still undervalued enough to redefine urban branding and marketing. The preservation of heritage buildings is a symbol of longevity, the durability of cultural values and innovation. People sense the potential of urban regeneration, but are too unaware of the impact generated by the power of example. Restoring a building enhances the sense of belonging to the community and focuses on collective responsibility initiatives, attracting social recognition.

1.

A number of specialists are involved in the development and planning of a city, especially with urban planners, architects and designers. A lesser known and rarely used profession in Romania is that of lighting specialist, is a lighting designer. And this even if lighting plays a very important role in the quality of public spaces, especially in the context of contemporary cities that are active non-stop. Culturebased development could be a significant factor for sustainable urbanization. Education and culture play an important role in revitalization projects. Cities with a unique and interesting culture can use this tradition to create coherent cultural 
policies, anchored in the past, but using modern urban design trends. Restructuring public spaces can be a good way to stimulate the local economy and promote cities. The 9 principles of ethical rehabilitation:

- Reorientation, Reuse (Repurpose + re-propose)

- Engaged participation

- Continuing education and experiments for innovation (Pedagogical Moments)

- Design. Beauty has magnetism. Defines the character. Promotes appreciation. Aesthetics is an aspect that attracts people. It offers value, importance and respect for the character of a community.

- Public Spaces (Place Over Time) Place refers more to the people who live in it and their activities than the space itself. Spaces must be flexible and agile and at the same time grow in an organic way.

- Networking (Constellations) Collaboration and interdisciplinarity help to bring together successful projects through the exchange of ideas and knowledge. A network is therefore created between the partners. Projects need visionaries, implementers, collaborators, evaluators and people to believe in that project. This forms a system of dynamic and creative cooperation.

- Platforms Many of our cities suffer from the same challenges - neglect, population loss, abandoned buildings and gentrification. Often the proposed solution is unique and does not integrate at the neighborhood level. But communities need a platform, which is a base where new social opportunities will be created. A platform is a mechanism that drives work - it creates conditions of multiplicity, composes ideas, expands relationships, generates opportunities and broadens access. Building platforms means developing opportunities for people to come together and communicate. People meet, exchange ideas and learn.

Cities are connected urban communities. The more responsibly and involved these communities act, the more the city transforms and becomes friendlier to the citizens. So it is an important step to create communities that want to get involved in transforming the place where they live and to ask themselves questions: "What else can be done? What can I do 10 blocks from my block? How do I share what I love to do with others?"

The proposal is a creative and interdisciplinary initiative, which aims to create a meeting space for designing new ways of life in which art, culture, social inclusion, science and technology intertwine and invites us to a collective effort to imagine and build a sustainable, inclusive and beautiful future for the mind and soul. 


\section{Urban Design and Planning}

The most common problems relate to infrastructure: pitted or unpaved streets, lack of parking spaces, sidewalks or bike lanes. Here comes another problem pollution. This is reported by many people who have suggested banning traffic in the central area, improving the quality of public transport or creating bike lanes for faster and healthier transport. Another problem often expressed is poor waste management and the non-existence of landfills in many areas. People have found that there is no selective garbage collection and would like this to be implemented. They also suggest the need for population education campaigns in this regard. Green spaces and children's playgrounds - their lack or poor arrangement are another worrying thing. There are also remarks about the aging population of certain small towns that seem to be forgotten somewhere in time. Development strategies are needed for these places to create facilities for this group of people who seem to be ignored at the moment. Smart methods of collaboration between local authorities and the community. An example might be the implementation of an application where each resident can be actively involved in the projects initiated by the authorities by answering certain surveys or reporting certain problems. The historical monuments are also mentioned by the citizens, this being a problem invoked in several cities of the country. Residents suggest using European funds to rehabilitate these historic symbols. It also mentions ways to inform residents about their past and importance.

The main issue is about cities for people or cities for cars. Solutions to the challenges of urban planning, design and policy, with topics ranging from open streets, cycling and infrastructure networks, interim interventions, placement metrics and mobility needs in informal neighborhoods. Focusing on Children. Streets are a city's largest continuous network of public space and mobility platform, allowing (or impeding) access to the city's resources. The design or redesign of urban streets through the lens of children shows why it is necessary to raise the bar for safety, accessibility and joy. Children's environment can have long-lasting effects on their health, physical and cognitive development and social well-being. When leaders in a city invest in designing children's streets, they create streets that better serve all people. In cities around the world, the streets are the front yards for children - and also their main means of transportation.

Children rely on the streets to get to school, to meet friends, to run errands with their parents and to play and explore their surroundings. But most streets were not built with children in mind. They were designed around cars, with wide traffic lanes and little space for human life. Parents and caregivers teach children that streets are dangerous places to avoid and to navigate them with only one adult.

This project aims to: 
- Emphasize the importance of street design that meets the needs of both children and citizens of the community

- $\quad$ Share tools, strategies, street design examples and case studies from around the world to help readers adapt to their local contexts

The aim of this project is to propose to build areas of the city as places for people, certainly, sustainability, affordable transport and fair choices that support a strong economy and a vibrant quality of life. Children's environment can have longlasting effects on their health, physical and cognitive development and social wellbeing.

The design of our discussions should focus on the places where we live and on our relationship with the environment, beyond the built space. It is a practical approach through which we want to discover beautiful, sustainable and inclusive ways of living and use them as a source of inspiration for the path we will follow.

\section{Design Thinking and its strengths}

It helps you discover people's needs, unmet so far, based on which you can innovate. Generates solutions with disruptive potential, not just incremental. Helps organizations learn faster.

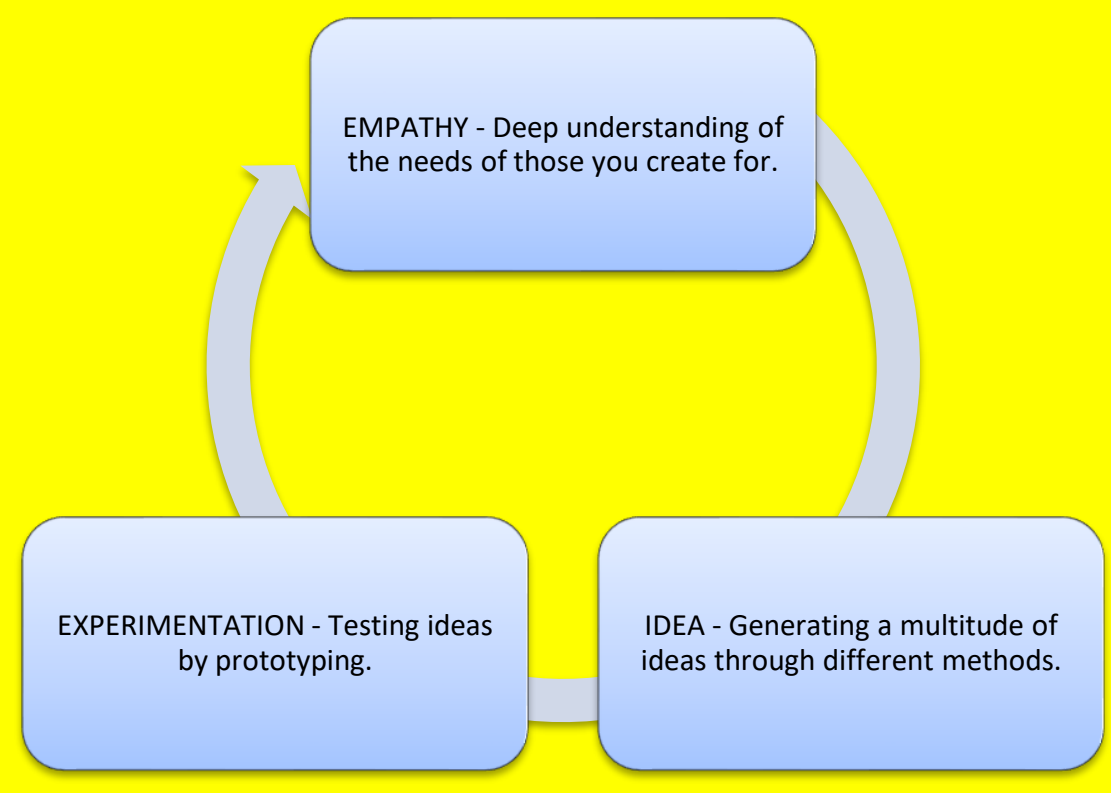

Fig. 1. Design Thinking pillars (the cycle of thinking)

Fig. 2. The design-thinking framework (Sarah Gibbons, 2016) 


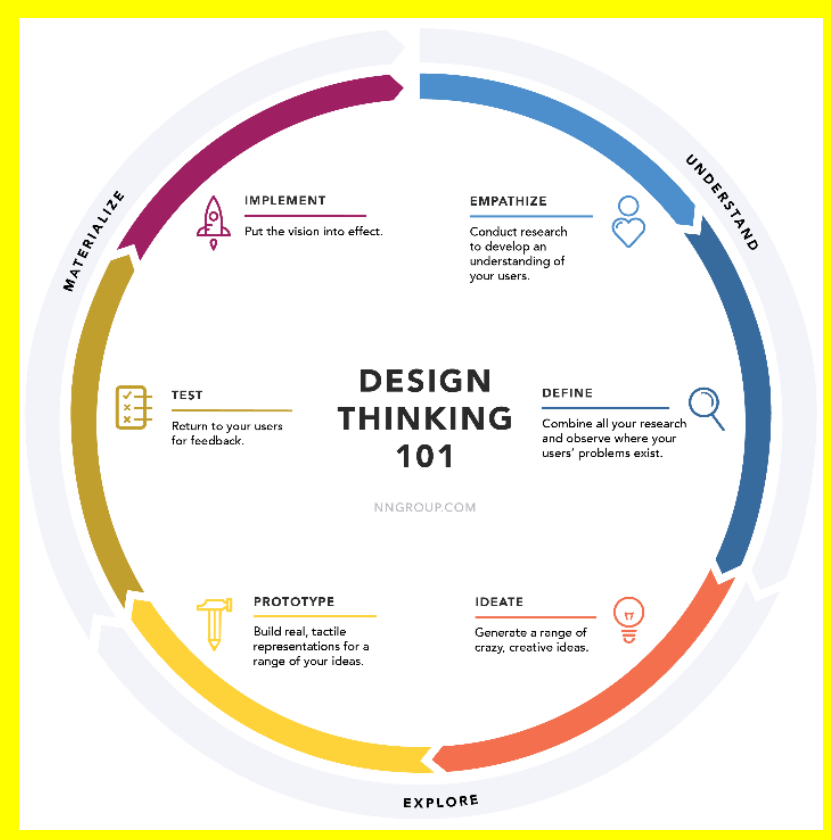

Design Thinking is somewhat understood as a tool for acquiring design optimization, but it is still far from being considered a tool for a competitive advantage. The main idea of this approach is based on the concept that the kind of thinking that designers use when solving problems for business or optimizing the work system can be applied. Instead of the usual decision-making methods, designers' resort to iterative processes. This translates into nonlinear reasoning and creative thinking.

Thus, according to Design Thinking theory, we can apply innovative schemes and creative actions during any type of project, or even business locations. A longterm and strategic approach, which means much more than the simplistic epithet "out of thought", often attached, can change the paradigm to constantly promote workplace innovation.

Design Thinking involves a creative, agile mindset that incorporates the ability to ask questions from a variety of points of view. These attributes are applicable not only for the design of the workplace, but for the evolution of a culture that quickly generates, shares and evaluates the economic viability of an idea. Design Thinking can also help differentiate a brand, while also providing a competitive advantage (Figure 3). 


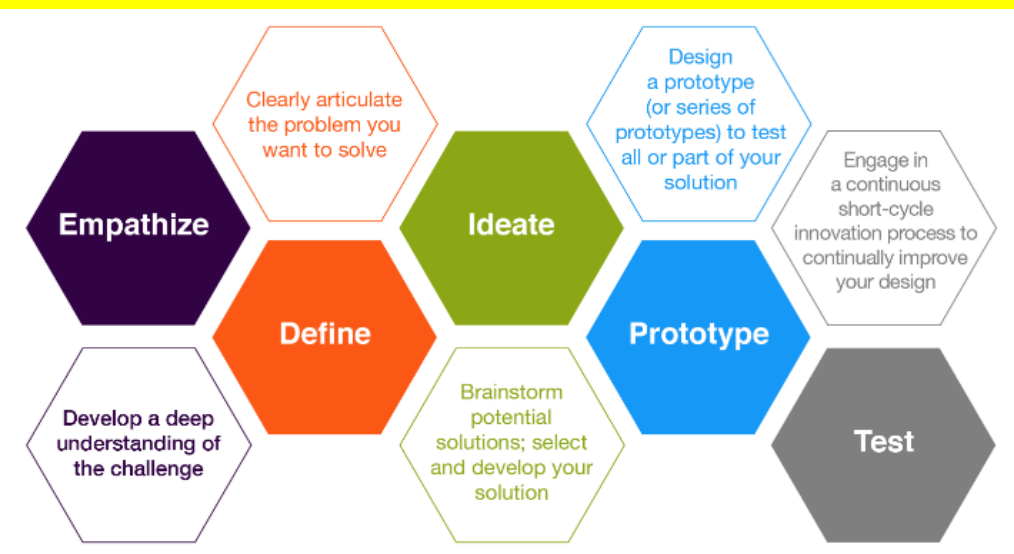

Fig. 3. Design Thinking practical approach (Design Thinking Practical Workshop, 2020)

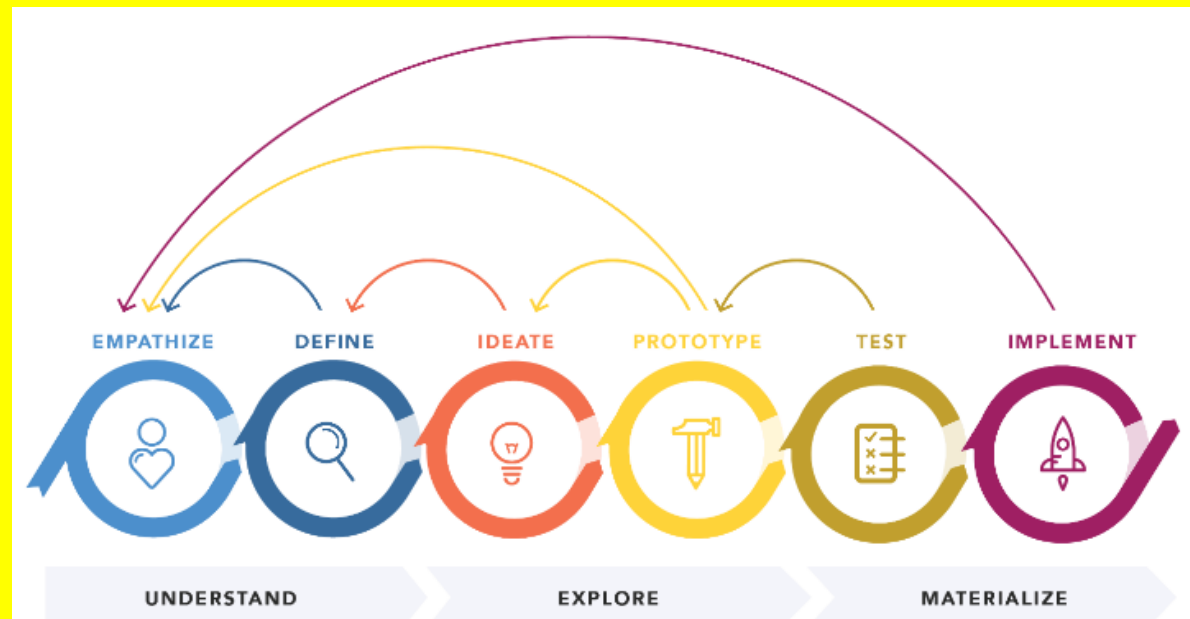

Fig. 4. Design Thinking lifecycle

Design Thinking: not just for the designer David Kelley, the founder of international design firm IDEO, is widely regarded as one of the pioneers of Design Thinking. They describe a "human-centered designer toolkit" that contains five elements to facilitate a design thinking process. They include (Figure 4):

- Empathize. It is never enough to offer basic services to contrasting points of view. The design mentality examines these points of view, the reasoning behind them, and considers their validity for defining the problem to be overcome.

- Define. This is not a place for vague ideas. The innovation model must be clearly defined, together with its purpose and the measurement of its efficiency.

- Ideational. This word "to imagine, conceive or form an idea or image" has been associated with Plato's philosophies, but he has found a place in modern design thinking through discussions that favor the generation of creative ideas. 
- Prototype. This tool goes beyond theory. It is a version of the product or approach that needs to be reviewed by a team then modified or modified to obtain the desired solutions.

- Test. The element, product, approach, etc., are tested through an iterative process' to assess and measure whether it effectively meets the objectives set out in the previous stages. The Interactive Design Foundation states that among the purposes of the testing stage are "redefining one or more problems and informing users' understanding ..."

Here is a summary of how each one manifests itself in the work environment:

- Volatility. The term represents a rapidly changing and unpredictable market due to foreign factors, from terrorism and politics, to disruptive technologies and socially accepted habits, customs and models.

- Uncertainty. Doubts about the state of the market or economy can impact decisions such as investments or expansion plans.

- Complexity. Unlike a complicated system, which is largely linear and easy to understand, the complex system is nonlinear with interactions and interdependencies, some of which can be easily obvious. Corporations are struggling with complexity due to a wide range of seemingly unrelated sources, such as international competition and attracting the best talent that can affect current and future planning.

- Ambiguity. Like uncertainty, an ambiguous environment produces multiple interpretations. Fear of ambiguity is likely to prevent decision making.

Design thinking is a concept used in both theory and practice, in the design realm, as well as the areas unrelated to design. It is a human-centred innovation process, a methodology for innovation. Design thinker is someone who bridges analytical and intuitive logics, and works towards the abductive logic. Apart from the usage in design realm, design thinking is increasingly being used by non-designers, and in areas such as business, management and other social sciences. Its indispensability in the management realm lays in the fact that design is nowadays shifting focus from products and brands towards a broader and more strategic range of organizational activities, in a human-centred way, to meet demands of the increasingly competitive marketplace. Customer experience has come to play a central role in demand for certain products and, as such, has become a decisive factor of success for different businesses, and tourism businesses and activities are no exception.

\section{Discussion}

A new cultural project for the community and a new meaning of the word beautiful: 
"Beautiful" means accessible and inclusive spaces, in which the dialogue between different cultures, disciplines, genres and generations offers us the opportunity to imagine a better place for all. It also means a more inclusive economy, in which wealth is well distributed and real estate prices are affordable.

"Beautiful" means sustainable solutions that create a balance between built-up areas and the planet's ecosystems. We can achieve this through a regenerative approach inspired by nature's cycles, ie reconstituting resources and protecting biodiversity.

"Beautiful" means experiences that enrich us, inspired by creativity, art and culture and responding to needs other than material ones. It means appreciating diversity and seeing it as an opportunity to learn from each other.

We propose that our discussions focus on the places where we live and on our relationship with the environment, beyond the built space. It is a practical approach through which we want to discover beautiful, sustainable and inclusive ways of living and use them as a source of inspiration for the path we will follow.

\section{Conclusion}

To show how design thinking can lead to the creation of a cultural project, with the aim of contributing to education and awareness of the value and importance of heritage. The project is the result of an exploratory, participatory action research brainstorming, thinking sessions for designing an informal interdisciplinary network of students and researchers from different fields of expertise. Its aim is to include both locals and visitors in a joint action to promote heritage as a tourist destination, but at the same time contributing to its sustainability, learning about it and being actively involved in a reception-reception relationship. with the city and its heritage. The project is proof that the new tools for a sustainable and innovative cultural experience through an even stronger, more creative and innovative tool, if it is interdisciplinary.

\section{References}

Bill Burnett, Dave Evans (2017). Design your life. Editura Publica.

Design Thinking Practical Workshop (2020, April 12). Retrieved March 02, 2021, from https://www.acceleratedfw.org/web/event/design-thinking-practicalworkshop

Evans, D., Burnett, B. (2017). Designing your life. Editura Publica.

Fleur MacDonald (2019, October 21). The city trying to make urban living good for your health. Retrieved March 02, 2021, from 
https://www.bbc.com/future/article/20191017-the-city-trying-to-makeurban-living-good-for-your-health

Kotler, Ph. (1999). Managementul Marketingului: Analiză, Planificare, Implementare, Control. Bucureşti: Teora.

Manzini, E. (2017). Designul, când toți suntem designer. Ed. Vellant.

Santos, M., Soares, M. (2014). Ergonomic Design Thinking. AHFE Conference. Advances in Ergonomics in Design, 560-571. Rebelo, F., Soares, M. (Eds.).

Sarah Gibbons (2016, July 31). Design Thinking 101. Retrieved March 03, 2021, from https://www.nngroup.com/articles/design-thinking/ 